\title{
Spor Tesisi Yöneticilerinin Tükenmişlik Düzeylerinin İş Doyum Düzeyleri İle İlişkisi ${ }^{1}$
}

\author{
DOI: $10.26466 /$ opus. 688985 \\ * \\ Beyza Özer* - Engin Işık Abanoz** - Utku Gönener*** Ahmet Gönener **** \\ * Yüksek Lisans, İstanbul Gelişim Üniversitesi, Sağlık Bilimleri Enstitüsü, İstanbul/Türkiye \\ E-Posta: beyzaozerr94@gmail.com \\ ORCID: \\ ** Dr. Öğr.Üyesi, İstanbul Gelişim Üniversitesi, Beden Eğitimi ve Spor Y. O, İstanbul/Türkiye \\ E-Posta: enginabanoz@hotmail.com \\ ORCID: $\underline{0000-0003-1198-9574}$ \\ *** Arş.Gör., Kocaeli Üniversitesi, Spor Bilimleri Fakültesi, Kocaeli/Türkiye \\ E-Posta: gonener.utku@gmail.com \\ ORCID: \\ **** Öğr. Gör. Dr., Kocaeli Üniversitesi, Spor Bilimleri Fakültesi, Kocaeli/Türkiye \\ E-Posta: ahmetgonener123@gmail.com \\ ORCID: $\quad \underline{0000-0003-3766-1016}$ \\ Öz
}

Çalışmamızda, spor işletmeleri yöneticilerinin tükenmişlik düzeyleri ile iş tatminleri arasındaki birlikteliğin incelenmesi amaçlanmaktadır. Çalışmanin eoreni İstanbul bölgesinde yerel yönetimlere bağlı ve 2019 senesinde faal durumda görevde bulunan spor işletmeleri yöneticileri, örneklemini ise seçkisiz ve gönüllülü̈k usulü ile çalışmamıza katılan 126 spor işletmeleri yöneticisi olarak görevde bulunan müdür ve müdür yardımcıları katılmaktadır. Katılımcılarımıza demografik bilgi formu, Minessota İş Doyumu Ölçeği ve Maslach Tükenmişlik Ölçeği içeren anket formu uygulanmaktadır. Tükenmişlik alt boyutlarından duygusal tükenmişlik seviyesinin düşük düzeyde, kişisel başarı alt boyut puanınn yüksek düzeyde, duyarsılaş̧ma alt boyutunun ise orta düzeyde olduğu görülmektedir. İş tatmini toplam puanlarma göre katılimclarm iş tatminlerinin yüksek olduğu belirlenmiştir. Tükenmişlik ile tükenmişlik alt faktörleriı arasinda olumlu boyutta güçlü bir ilişki bulunmaktadır $(p<0,05, \beta=0,664, \beta=0,878, \beta=0,442)$. Işs tatmini ile iş tatmini alt boyutlar arasında da olumlu ve güçlü ilişki bulunmaktadır ( $p<0,05, \beta=0,917, \beta=0,909)$. Iş̧ tatmini alt boyutlar ile tükenmişlik alt boyutları aralarında istatistiksel bir ilişki bulunmamıştır(p>0,05) Bütün tükenmişlik puanı ile iş tatmini bütün puanları arasındaki ilişki istatistiksel olarak anlamlı çıkmamışır ( $p>0.05)$. Sonuçlara bakıldı̆̆ında, tükenmişlik ile iş doyumları arasında istatistiksel olarak bir ilişki bulunmamaktadir.

Anahtar Kelimeler: İş doyumu, tükenmişlik, spor yöneticileri

\footnotetext{
${ }^{1}$ Bu makale 1. Yazarın Yüksek Lisans Tezi'nden üretilmiştir.
} 
ISSN: 2528-9527

E-ISSN : 2528-9535

YIl Year: 10

Cilt Volume: 17

Sayı Issue:36

\title{
The Relationship between Burnout Level and Job Satisfaction Level of Sports Facilities Managers
}

\begin{abstract}
In this study, it was aimed to investigate the relationship between burnout levels and job satisfaction of sports facilities managers. The universe of the research is composed of sports facility managers who are active in 2019 in the Istanbul region and actively functioning in 2019, and the sample is composed of 126 sports facility managers who participated in the research in a random and voluntary manner. A questionnaire including demographic information form, Minnesota Job Satisfaction Scale and Maslach Burnout Inventory was applied to the participants. Among the burnout subscales, the level of emotional exhaustion is low, the personal accomplishment subscale score is high, and the depersonalization subscale is medium. It was determined that the job satisfaction of the participants was high according to the job satisfaction total scores. There is a strong positive correlation between burnout and burnout subdimensions ( $p<0.05, \beta=0.664, \beta=0.878, \beta=0.444$ ). There is a strong positive relationship between job satisfaction and job satisfaction sub-dimensions $(p<0.05, \beta=0.917, \beta=0.909)$. There was no statistically significant relationship between job satisfaction subscales and burnout subscales ( $p>0.05)$. The relationship between total burnout score and job satisfaction total scores was not statistically significant $(p>0.05)$. As a result, there was no statistically significant relationship between burnout and job satisfaction.
\end{abstract}

Keywords: Job satisfaction, Sport, Burnout, Sport managers 


\section{Giriş}

Yönetim, devlet kurumları, özel şirketler, yerel yönetimler, eğitim kurumları ve kuruluşları gibi kurumsal yapılarda olduğu gibi bir spor kulübü veya spor işletmeleri gibi her seviyedeki yapılanmada mevcuttur. İnsanların ortak hedeflere ulaşmak için ekipler halinde bir araya geldiği her durumda, her bireyin çabalarının etkili bir sonuca ulaşmak için koordine edilmesi çok önemlidir. Bu nedenle yönetim, grup içindeki insan, maddi, finansal ve geçici kaynakların başarılı bir şekilde yönlendirilmesini ve koordine edilmesini içerir, böylece kuruluş ve üyeleri tarafından belirlenen hedeflere belirli plan ve program çerçevesi içerisinde ulaşmak kolaylaşır. Örgüt içindeki bu tür yönetim işlerinden sorumlu olan bireyler gerçekten de yönetim görevleri yürütmektedir (Sánchez, Arturo ve Suárez, 2018). Spor sektöründe yer alan her türlü kurum ve tesislerde genel müdür, genel müdür yardımcısl, şube müdür ve yardımcıları, tesis müdür ve yardımcları gibi yönetim pozisyonunda bulunan kişiler spor yöneticileri olarak tanımlanır. Spor yöneticilerinin ana görevlerinden biri, hem spor işletmeleri kullanıcılarının yani tesis üyelerinin, hem de spor eğitmenlerinin memnuniyetinin mümkün olduğunca yüksek kalmasını sağlamaktır. Spor yöneticileri insanlarla çok fazla yüz yüze geldiklerinden psikolojik, fiziksel ve zihin tükenmeleri yaşamakta ve bu yüzden iş tatminleri de azalmaktadır. Bu azalma, spor yöneticilerinin, iş arkadaşlarına, çevresine, aile ve insan iletişimini etkilemekte sorumluluk duyduğu işin işlevselliğini sağlamakta zorlanır. Spor yöneticilerinin veriminin azalması iş yerinin ve topluluğun ümidini etkilemektedir. Bundan dolayı, spor yöneticilerinin iş tatmini durumları önem arz eder (Taşğın, 2004, s.170). Öte yandan, kuruluşların yönetim modelleri, organizasyon tipleri, eğilimleri, çalışanların iş doyumu konularında problemlerin giderilmesine yönelik yönetim uygulamalarının anlaşılması, rekabet avantajı elde edilmesine yardımcı olabilir. Bununla birlikte, bu anlayış kuruluş için verimliliği ve etkinliği garanti etmez, bu nedenle, edinilen bilginin yönetilmesi, kuruluş tarafından belirlenen hedeflere ulaşmak için uyum sağlamayı da içerecektir (Grimaldi Puyana, Perez Villalba, Bernal Garcıa ve Sanchez Oliver,2018). Tükenmişlik kavramı ise hissi istekleri bulunan yerlerde fazla çalışmalardan dolayı, çalışanlara ve işteki durumlara karşı negatif bir tutum sağlar. Fiziki olarak tükenen ve ilerleme ile bağlantılı bir durum gibi tanımlanabilir. Tükenmişlik sorunu önce- 
likle 1974 yılında Herbert Freudenbergr değerlendirmiştir (Marakoğlu, Kargin ve Armutlukuyu, 2013, s. 104). Maslach and Jackson (1986), tükenmişliği; Kişi; (a) hissizleşmek (tükenmişlik görüşü bireyler arası boyutu ve çalıştı̆̆ bireylere karşı mutsuz, sert, umursamaz bir durum özümser ), (b) duygusal tükeniş (tükenmişliğin kişisel boyutu) ve duygusal yorgunluk (çalıştı̆̆ı yerde yorgunluk ve fiziki hissizlik (uyku hali, üşüme, baş ağrıları)) ardından (c) şahsi muvaffakiyet durumu eksilmesi (olgunluk ve başarıda eksilme) olarak tanımlanmaktadır (Soysal 2011, s.15 ). Benlik hürmeti, sürekli halsizlik, biçare durumu ve ümitsizlik yok olmasıyla karakterize fiziki, duygusal ya da entelektüel bitme ile bilinen bir sorun şeklinde, kişinin mesleki hayatında ve başka bireylerle olan bağlantılarında olumsuzluk, duygusal tükenme gibi seçenekleri de vardır. Tükenmişlik kelimesi açıklamalarında iş yapanlar üstünde negatif durum ve sosyo-psikolojik yönleri olmaktadır. Tükenmek literatürde öncelik olarak sağlık ile sosyal hizmetler alanlarında araştırmalar yapılmış ve çalışılmıştır. Zira sağlık ve sosyal hizmet alanlarında, psikoloji ve davranışa göre hareketlerin fazlaca tükenmişliğe sebep olması durumunda incelemeler yapılmaktadır(Yakut, Gül Kapısız, Durutuna ve Evran. 2013, s. 1564). İş tatmini ismi en başta 1920'li senelerinde araştırıldı, ancak iş tatmininin ehemmiyeti 1940'lı yıllarda anlaşıldı. İş hayatı, çalışanlara sadece iş ile ilgili deneyimler kazandırmakla yetinmez, hem de her çalışma gününde beliren değişik duyguların yığılmasına da zemin olur. Bu tecrübeler neticesinde bireyin çalışmak için beyinsel ve hissi bir durumu olmaktadır (Eğinli 2009, s. 36). İş tatmini açıklaması, çalışma yerinin ait olduğu durumları ve çalışanların talepleriyle eşleştiğinde ve mesai yapan bireylerin hoşuna gittiğini belirlediğinde ortaya çıan bir terimdir. İş tatmini açıklaması, çalışanların işlerini mutlu ve beğenili bir his olarak belirlemeleridir. İş doyumu “bir bireyin bilinçli veya bilinçsiz bir şekilde elde etmek istediği şey olarak tanımlanan değerlerin" tanımlamasıdır. Çalışma ortamında ortaya çıan bu durumlarının oranı fazlalaştıkça iş tatmini de fazlalaşır (Özaydın ve Özdemir 2014, s. 253).Yaptığımız çalışmada, spor işletmeleri yöneticilerinin tükenmişlik dereceleriyle işe olan tatminleri arasında bağlantıların tetkik edilmesi amaçlanmiştr. 


\section{Yöntem}

Bu bölümümüzde, çalışmamızın hedefi, ehemmiyeti, genişliği, veri toplama araçları, verilerin analizinden bahsedilmektedir.

\section{Araştırmanın amacı}

Spor bilimlerinde iş tatmini, spor kuruluşarında mesai yapan tesis yöneticilerine kadar herkesle ilgili önemli ve gerekli bir araştırmadır. Meslekte tükenmişlik de, buna benzer işletmelerde iş yapanlar üzerinde mühim olup, bu kuruluşlarda iş niteliğinin etkili olması, umumi olarak toplumu spora itmek ve başarıyı da bağlamaktadır. Bu sebep ile çalışmamızda, spor işletmeleri yöneticilerinin tükenmişlik düzeyleri ve iş tatmini seviyeleri arasındaki bağlantının incelenmesi amaçlanmaktadır. Spor işletmeleri yöneticilerinin tükenmişlik düzeyleri ve iş tatmini seviyeleri arasındaki ilişkinin incelenmesini hedefleyen bu çalışma ilişkisel tarama modelinde betimsel bir çalışma olmuştur. İlişkisel çalışmalar her ne kadar gerçek anlamda bir sebebin var olduğunu ispatlamasa da bazı ileri düzey istatistik tekniklerinin değerlendirilmesiyle ilişkisel çalısmalarla sebep-sonuç bağlantısına ait çıkarımlarda bulunmak muhtemel olacaktır (Karaçam ve Pulur, 2019).

\section{Evren ve örneklem}

Çalışmamızın evrenini İstanbul bölgesinde, 2019 senesinde çalışan spor tesis yöneticileri, örneklemini ise, gönüllülük yöntemine göre çalışmaya katılacak olan 126 spor tesisleri yöneticileri meydana getirecektir. Araştırmada bu çerçevede, bütün sayım örnekleme ve gönüllülük usulüne bağlı basit tesadüfi örnekleme yöntemlerinden faydalanmıştır. Bu sebeple, İstanbul bölgesinde yerel yönetimlerine bağlı spor tesislerinin müdür ve müdür yardımcısı pozisyonundaki yöneticilerine ulaşlarak, istekli olanlarla çalşsma verileri toplanmıştır.

\section{Veri toplama aracı}

Çalışmamızda veri toplamak amacıyla 3 kısımdan oluşan anket kullanılmaktadır. Anketin 1. kısım demografik bilgileri kapsayan form, sonraki bölüm Maslach Tükenmişlik Ölçeği ve üçüncü kısımda Minessota İş Doyumu Ölçeği Kısa Formu kullanılmıştır. 


\section{Verilerin toplanması}

Yöneticilere konuyla ilgili umumi bilgiler iletildikten sonra, çalışma anketine katılmaya gönüllü olup olmadıkları sorulmuştur. Çalışmaya katılmak için gönüllü bulunan spor işletmeleri yöneticilerine bundan sonra araştırma anket formu verilip herhangi bir soru olursa yantlamak için anketlerin bitimine kadar beklenmiştir. Araştırmada veri toplamak amacıyla demografik bilgileri içeren aşamadan oluşan anket, Maslach Tükenmişlik Ölçeği ve Minnesota İş Doyumu Ölçeği Kısa Formu kullanılmaktadır. Maslach tükenmişlik ölçeğinde bulunan ; 1, 2, 3, 6, 8, 13, 14, 16 ve 20 no'lu maddeler duygusal tükenmeyi; 5, 10, 11, 15 ve 22 no'lu maddeler duyarsızlaşmayı; 4, 7, 9, 12, 17, 18, 19 ve 21 no'lu maddeler deki tanımlamalarsa kişisel başarıyı hesaplamada kullanılan tutumları ifade etmektedir.( MTÜ ) tükenmişliği üç alt kısımda ele alır. Hepsi 22 deyişte bulunan ölçekte tükenmişlik; duygusal tükenme, duyarsızlaşma ve düşük bireysel başarı olmakla beraber alt kısımlara bölünmektedir (Cronbach Alfa: Duygusal Tükenme $=0.83$, Duyarsizlaşma $=0.71$ ve Düşük Kişisel Başarı = 0.72). Maslach Tükenmişlik Ölçeği'nde bulunan bütün ifadelere katılma derecesini gösteren şıklar vardır. 1-5 arasında puanlanan ölçekte; "kesinlikle katılmıyorum" şıkkı 1 puan; "katılmıyorum" şıkkı 2 puan; "kararsızım" şıkkı 3 puan; "katılıyorum" şıkk1 4 puan ve "kesinlikle katılıyorum" şıkkı 5 puan olaraktan değerlendirilmiştir. Ölçeğin Türkçe'ye çevirme denemeleri Ergin (1992) tarafından sağlanmaktadır ( Şıklar ve Tunalı, 2012, s.76 ). Maslach Tükenmişlik Ölçeği'nin üç kısımdan toplayabileceği puan oranları ve bu oranların karşılık belirttiği seviyeler Tablo 1'de yer almıştır (İnce ve Şahin,2015).

Tablo 1. MTE Puanlama Anahtarn

\begin{tabular}{|c|c|c|c|}
\hline \multicolumn{4}{|l|}{ Tükenmişlik } \\
\hline & Düşük Düzey & Orta Düzey & Yüksek Düzey \\
\hline Duygusal Tükenme & $0-16$ & $17-26$ & 27 ve üzeri \\
\hline Duyarsızlaşma & $0-8$ & $9-13$ & 14 ve üzeri \\
\hline Kişisel Başarı & 37 ve üzeri & $31-36$ & $0-30$ \\
\hline
\end{tabular}

Weiss, Davis, England ve Lofguist (1967) aracılı̆̆ ile çalışılan Minnesota İş Doyum Ölçeği Baycan (1985) aracılığıyla Türkçe'ye adepte ederek geçerlilik ve güvenirlik araştırmaları yapılmaktadır (Cronbach alfa $=0,77$ ). Minnesota İş Doyum Ölçeği 1-5 arasında puanlanan beşli likert tipi ölçeği oluşturur. 
Ölçek puanlamasında, Hiç memnun değilim; 1 puan, Memnun değilim; 2 puan, Kararsızım; 3 puan, Memnunum; 4 puan, Çok memnunum; 5 puan olarak değerlendirilmektedir. Ölçekte zıt puanlama maddesi yoktur. Minnesota İş Doyum Ölçeği içsel, harici ve genel tatmin seviyelerini sınırlayıcı alanlara sahip 20 içerikten oluşmaktadır. Alt boyutlardan iç tatmini 1, 2, 3, 4, 7, 8, 9, 10, 11, 15, 16, 20 maddelerden oluşmaktadır. Başarılı olmak, tanıma ve ya beğenilme, işin kendisi, işin yükleri, terfiyle birlikte görev değişikliği gibi işin içsel niteliğine ilişkin memnuniyetlerle ilgili maddeler oluşturmaktadır. Alt boyutlardan dışsal doyum ise 5, 6, 12, 13, 14, 17, 18, 19 maddelerinden oluşmuştur. İşletme politikası ve yönetimi, denetim şekli, yönetici, çalışma ve astları ile olan ilişkiler, çalışma durumları, beklenen maaş vb. ögelerden oluşturulmaktadır. Genel doyum ölçekte bulunan bütün maddeler 1, 2, 3, 4, 5, 6, 7, $8,9,10,11,12,13,14,15,16,17,18,19,20$ numaraları kapsamaktadır. Bir de Minnesota İş Tatmin Ölçeğinin öncesine katılanlardan öğrenilmek için cinsiyet, yaş, unvan, iş tecrübesi ve öğrenim seviyesi gibi demografik bilgiler bölümü eklenmiştir ( Yelboğa, 2007, s. 6 ). Weiss vd. (1967) Minnesota doyum ölçeğinin 20-100 aralığında puanlanan ve puan seviyesi arttıkça iş tatmininin arttı̆̆ını gösteren bir ölçek olduğunu belirtmiştir ve puan seviyesi 25 ve altı düşük iş tatmini, 26- 74 orta seviye iş tatmini ve 75 ve üzeriyse yüksek iş tatmini olarak göstermiştir (Köroğlu,2012). Demografik bilgi formu, Minessota İş Doyumu Ölçeği Kısa Formu ölçekleri kullanılabilmesi için kurumların genel müdürlüğünden izin alınmıştır. Araştırma verileri araştırmacı tarafından toplanmıştır.

\section{Verilerin analizi}

Çalışmada biriktirilen verilerin analizi sırasında, SPSS 17.0 for Windows programı kullanılmaktadır. Nominal ve ordinal verileri tanımlarken Frekans Analizi, ölçüm parametrelerinin belirtilmesi amacıyla ortalama ile standart sapma değerleri kullanılmaktadır. Ölçek seviyelerinin ayrım analizi ve hipotez testlerinden başta, verilerin dağılımının normalliği amacıyla Kolmogorov Smirnov testi yapılmaktadır. Testin neticesinde normal dağılan parametrelerin ikili grup ayrımı Independent Samples T-testiyle, 2 ve fazlası grupların ayrımı One-Way ANOVA testi analiz etmektedir. Dağılmayan verilerin 2 li grup ayrımları için Mann Whitney-U testi, ikiden fazla grup ayrımında Krus- 
kal Wallis-H testi uygulanmaktadır. Korelasyon çözümlemesi parametrik veriler için Pearson's Korelasyonu, nonparametrik veriler içinse Spearman's rho korelasyon analizi kullanılmıştır. Tüm analizler yüzde 95 emniyet aralığıyla gerçekleşmiştir.

\section{Bulgular}

Tablo 1. Çalışmaya Dahil Olan Bireylerin Bazı Demografik Özelliklere Göre Dağılımlan

\begin{tabular}{|c|c|c|c|}
\hline & Değişken & $\mathbf{N}$ & $\%$ \\
\hline \multirow{2}{*}{ Cinsiyet } & Erkek & 118 & 93,7 \\
\hline & Kadın & 8 & 6,3 \\
\hline \multirow{3}{*}{ Yaş Grubu } & 26-35 aralığ & 59 & 46,8 \\
\hline & $36-45$ aralığ & 56 & 44,4 \\
\hline & 46 ve üzeri & 11 & 8,7 \\
\hline \multirow{3}{*}{ Eğitim Durumu } & Ön lisans & 20 & 15,9 \\
\hline & Lisans & 97 & 77,0 \\
\hline & Lisansüstü & 9 & 7,1 \\
\hline \multirow{2}{*}{ Medeni Durumu } & Evli & 101 & 80,2 \\
\hline & Bekar & 25 & 19,8 \\
\hline \multirow{3}{*}{ Aylık Gelir } & 4001-5000 TL aralığ & 16 & 12,7 \\
\hline & 5001-6000 TL aralığı & 69 & 54,8 \\
\hline & 6001 TL ve üzeri & 41 & 32,5 \\
\hline \multirow{2}{*}{ Aile Tipi } & Çekirdek aile & 102 & 81,0 \\
\hline & Geniş aile & 24 & 19,0 \\
\hline \multirow{3}{*}{ Mesleki Tecrübe } & $1-5$ sene & 34 & 27,0 \\
\hline & $5-10$ sene & 57 & 45,2 \\
\hline & $10-15$ sene & 35 & 27,8 \\
\hline
\end{tabular}

\section{Demografik bulgular}

Çalışmada yer alan yöneticilerin yüzde 93.7'si erkek ve yüzde 6.3'ü kadındır. Genele bakıldığında erkeklerin fazlalıkta olduğu görülmüş̧ür. Önümüzdeki dağılım, ülkemizde genelde erkek yönetici olduğu fikrine katılmaktadır. Araştırmaya ortak olan yöneticilerin yüzde $46.8^{\prime}$ i $26-35$ aralığı, yüzde $44.4^{\prime} \ddot{u}$ $36-45$ ve yüzde 8.7'si 46 ve üstü yaşa sahiptir. Sonuçta ülkemizde olan spor kurumlarının yöneticilerinin demografisini desteklemektedir. Katılımcıların yüzde 15.9'u ön lisans, yüzde 77.0'si lisans ve yüzde 7.1'i yüksek lisans eğitimi almıştır. Araştırma örnekleminin yüzde 80.2'si (yani büyükçe bir bölümü) evli, yüzde 19.8'i ise bekardır. Çalışmaya dahil olan spor yöneticilerinin yüzde 12.7'si 4001-5000 TL aralı̆̆ı, yüzde 54.8'i 5001-6000 TL aralığı, yüzde 32.5' $\mathrm{i}$ ise 6001 TL ve üstünde aylık maddi gelir kazanmaktadır. Aylık gelir çoğunlukla 5000 TL'nin üzerindedir. Katılanların yüzde 81.0'i çekirdek 
aileye, yüzde 19.0'u ise geniş aileyle yaşadığı görülmüştür. Dağılımdan çekirdek aile fazla gözükmüş olsa dahi geniş aile seviyeleri mühim ölçüdedir. Araştırmaya dahil olan spor yöneticilerinin yüzde 27.0'si 1-5 sene arası, yüzde 45.2'si 5-10 sene arası, yüzde 27.8'i 10-15 sene süresi iş tecrübesine sahiptir Genellikle orta düzeyde 5-10 yıl arası tecrübeli spor yöneticileri araştırmaya katılmıştır.

Tablo 2. Maslach Tükenmişlik Ölçeği Maddelerine Verilen Cevaplara İlişkin Sonuçlar

\begin{tabular}{lllll}
\hline & Cinsiyet & $\mathbf{N}$ & Toplam & SS \\
\hline Duygusal_Tükenmişlik & Kadın & 8 & 15,56 & 3,47 \\
& Erkek & 118 & & 3,27 \\
\hline Kişisel_Başarı & Kadın & 8 & 14,76 & \\
& Erkek & 118 & & 1,80 \\
\hline Duyarsızlaşma & Kadın & 8 & 10,69 & 5,03 \\
& Erkek & 118 & 39,98 & \\
\hline Tükenmişlik & Kadın & 8 & & \\
& Erkek & 118 & & \\
\hline
\end{tabular}

Tükenmişlik alt boyutlarından duygusal tükenmişlik seviyesinin düşük düzeyde, kişisel başarı alt boyut puanının yüksek düzeyde, duyarsızlaşma alt boyutunun ise orta düzeyde olduğu görülmektedir.

Tablo 3. İş Tatmini Maddelerine Verilen Cevaplara İlişkin Sonuçlar

\begin{tabular}{lllll}
\hline & Cinsiyet & N & Toplam & SS \\
\hline İçsel Tatmin & Kadın & 8 & 46,12 & 3,62 \\
& Erkek & 118 & & \\
\hline Dişsal Tatmin & Kadın & 8 & 45,95 & 1,87 \\
& Erkek & 118 & & 4,83 \\
\hline İş Tatmini & Kadın & 8 & 92,07 & \\
& Erkek & 118 & & \\
\hline
\end{tabular}

Araştırmamızda yer alan yöneticilerin iş tatmini, içsel tatmin ve dışsal tatmin seviyelerinin yüksek olduğu görülmektedir. 
Tablo 4. Bütün Tükenmişlik Seviyelerinin Demografıksel Özelliklere Göre Farkı Amacıyla Yapılan Analiz Sonuçları

\begin{tabular}{|c|c|c|c|}
\hline & Toplam & SS & p \\
\hline \multicolumn{4}{|l|}{ Cinsiyet } \\
\hline Erkek & 41,19 & 6,53 & 0.309 \\
\hline Kadın & 38,50 & 5,26 & \\
\hline \multicolumn{4}{|l|}{ Yaş } \\
\hline $26-35$ & 41,19 & 6,71 & 0.198 \\
\hline $36-45$ & 41,41 & 6,32 & \\
\hline 46 ve üzeri & 38,09 & 5,72 & \\
\hline \multicolumn{4}{|l|}{ Ĕ̈itim } \\
\hline Ön lisans & 42,55 & 7,88 & 0.679 \\
\hline Lisans & 40,84 & 6,23 & \\
\hline Lisansüstü & 39,56 & 5,73 & \\
\hline \multicolumn{4}{|l|}{ Medeni durum } \\
\hline Evli & 40,88 & 6,55 & 0.627 \\
\hline Bekar & 41,56 & 6,22 & \\
\hline \multicolumn{4}{|l|}{ Aylikgelir } \\
\hline 4001-5000 TL aralı̆ı & 39,63 & 6,27 & 0.562 \\
\hline 5001-6000 TL aralı̆ & 40,99 & 6,72 & \\
\hline 6001 TL ve üzeri & 41,61 & 6,17 & \\
\hline \multicolumn{4}{|l|}{ Aile tipi } \\
\hline Çekirdek aile & 40,79 & 6,59 & 0.313 \\
\hline Büyük aile & 41,96 & 5,97 & \\
\hline \multicolumn{4}{|l|}{ Mesleki deneyim } \\
\hline $1-5$ sene & 40,09 & 6,73 & 0.155 \\
\hline 5-10 sene & 42,30 & 6,48 & \\
\hline $10-15$ sene & 39,83 & 5,99 & \\
\hline
\end{tabular}

Toplam tükenmişlik seviyesi erkeklerde, 36-45 arası yaş aralığı olan katılımcılarda, ön lisans mezunu, bekar olup, aylık geliri 6001 TL ve fazla bulunanlarda, geniş aileyle yaşayan, 5-10 yıl meslek tecrübesi bulunanlarda daha yüksektir. Tüm gruplar arasında istatistiksel olarak anlamlı farklılık bulunmamıştır ( $\mathrm{p}>0.05)$. 
Tablo 1.5 Tükenmişlik ile İş Tatmini Arasında İlişki için Uygulanan Korelasyon Analiz Sonuçlarn

\begin{tabular}{|c|c|c|c|c|c|c|c|c|}
\hline & Tüke & mişlik & $\begin{array}{l}\text { Duygusal } \\
\text { Tükenmişlik }\end{array}$ & $\begin{array}{l}\text { Kişisel } \\
\text { Başarı }\end{array}$ & $\begin{array}{l}\text { Duy- } \\
\text { arsızlaşma }\end{array}$ & $\begin{array}{l}\text { İş } \\
\text { Tatmini }\end{array}$ & $\begin{array}{l}\text { İçsel } \\
\text { Tatmin }\end{array}$ & $\begin{array}{l}\text { Dişsal } \\
\text { Tatmin }\end{array}$ \\
\hline \multirow{3}{*}{ Tükenmişlik } & $\mathrm{r}$ & 1,000 & ,664 &, $878^{* *}$ &, $442^{* *}$ &,- 033 &,- 023 & -017 \\
\hline & $\mathrm{p}$ & . & ,000 & ,000 & ,000 & ,712 & ,800 & ,854 \\
\hline & $\mathrm{N}$ & 126 & 126 & 126 & 126 & 126 & 126 & 126 \\
\hline \multirow{3}{*}{$\begin{array}{l}\text { Duygusal } \\
\text { Tükenmişlik }\end{array}$} & $\mathrm{r}$ & $664^{* *}$ & 1,000 &, $402^{* *}$ &,- 141 &,- 015 &,- 017 &,- 033 \\
\hline & $\mathrm{p}$ &, 000 & . &, 000 & ,114 & ,871 & ,850 & ,714 \\
\hline & $\mathrm{N}$ & 126 & 126 & 126 & 126 & 126 & 126 & 126 \\
\hline \multirow{3}{*}{ Kişisel Başarı } & $\mathrm{r}$ & $878^{* *}$ & $402^{* *}$ & 1,000 & $439^{* *}$ &,- 029 &,- 034 & ,008 \\
\hline & $\mathrm{p}$ &, 000 &, 000 & . &, 000 & ,751 & ,703 & ,929 \\
\hline & $\mathrm{N}$ & 126 & 126 & 126 & 126 & 126 & 126 & 126 \\
\hline \multirow{3}{*}{ Duyarsızlaşma } & $\mathrm{r}$ & $442^{* *}$ &,- 141 & $439^{* *}$ & 1,000 &,- 072 &,- 003 &,- 074 \\
\hline & $\mathrm{p}$ & ,000 & ,114 &, 000 & $\cdot$ & ,421 & ,971 & ,412 \\
\hline & $\mathrm{N}$ & 126 & 126 & 126 & 126 & 126 & 126 & 126 \\
\hline \multirow{3}{*}{ İş Tatmin } & $\mathrm{r}$ &,- 033 &,- 015 &,- 029 &,- 072 & 1,000 & ,917 &, $909^{* *}$ \\
\hline & $\mathrm{p}$ & ,712 & 871 & ,751 &, 421 & . & ,000 &, 000 \\
\hline & $\mathrm{N}$ & 126 & 126 & 126 & 126 & 126 & 126 & 126 \\
\hline \multirow{3}{*}{ İç Tatmin } & $\mathrm{r}$ &,- 023 &,- 017 &,- 034 &,- 003 & $917^{*+4}$ & 1,000 & $717^{* *}$ \\
\hline & $\mathrm{p}$ &, 800 & ,850 & ,703 & ,971 & ,000 & . &, 000 \\
\hline & $\mathrm{N}$ & 126 & 126 & 126 & 126 & 126 & 126 & 126 \\
\hline \multirow{3}{*}{ Dişsal Tatmin } & $\mathrm{r}$ &,- 017 &,- 033 & ,008 &,- 074 & $909^{* *}$ &, $717^{* *}$ & 1,000 \\
\hline & $\mathrm{p}$ & 854 & ,714 & ,929 & 412 & ,000 & ,000 & . \\
\hline & $\mathrm{N}$ & 126 & 126 & 126 & 126 & 126 & 126 & 126 \\
\hline
\end{tabular}

Tükenmişlik ile tükenmişliğin alt seviye ilişkilerinde olumlu olarak kuvvetli bir ilişki bulunmaktadır( $p<0,05, \beta=0,664, \beta=0,878, \beta=0,442)$. İş tatmini ile iş tatmini alt boyutları arasında olan ilişkilerde olumlu olarak güçlü bir ilişki bulunmaktadır $(\mathrm{p}<0,05, \beta=0,917, \beta=0,909)$. İş tatmini alt boyutları ve tükenmişlik alt boyutları arasında istatistiksel bir ilişki bulunmamıştır(p>0,05) Toplam tükenmişlik puanı ile iş tatmini bütün puanları arasında ise ilişki bulun$\operatorname{mam}$ ştır$(p>0.05, \beta=-0,033)$.

\section{Tartışma ve Sonuç}

Araştırmamızda spor işletmeleri yöneticilerinin tükenmişlik ve iş tatmini se- 
viyeleri araştırılarak, tükenmişlik düzeylerinin iş tatminini ne şekilde etki ettiği araştırılmıştır. Çalışmaya bu pencereden, spor işletmelerindeki yöneticilere anket uygulanarak tükenmişlik ve iş tatmini seviyeleri ortaya koyulmuş ve tükenmişlik ile iş tatmini arasındaki ilişkiye bakılmıştır. Yapılan bir çalışmada, cinsiyete göre duygusal tükenme $(\mathrm{p}=0.148)$, hissizleşme $(\mathrm{p}=0.074) \mathrm{ki}-$ şisel başarının $(\mathrm{p}=0.218)$ istatistiki olarak anlamlı seviyede farklılaşmadığını gösterilmiştir ( Akkoç ve Tunç, 2015, s.16). Çalışmanın devamında yaş aral1ğında her üç tükenme seviyesi istatistiksel olarak anlamlı fark göstermemiştir. Medeni duruma göreyse yalnızca bireysel başarı seviyesi anlamlı durumda farklılaşmıştır $(\mathrm{p}<0.05)$. Bireysel başarı seviyesinin yaşa göre anlamlı düzeyde değiştiği, 36 ve üst yaşlarda bulunanlarda en fazla seviyede olduğu, farklı boyutların ise anlamlı farklılık göstermediği tespit edilmiştir( Altay, Gönener ve Demirkiran, 2010, s.15 ). Aynı araştırmada medeni duruma ve mezun olunan seviyeye göre tükenmişlik seviyeleri arasında farklılık anlamlı değildir. Bir başka araştırmada, bireysel başarı seviyesi anlamlı bir derecede 51 ve üstyaşta daha fazla olduğu, ancak farklı seviyelerin anlamlı fark göstermediği belirtilmiştir( Ardıç ve Polatçı, 2008, s. 82). Denk durumlarda medeni durumlarını düşünürsek tükenmişlik seviyeleri anlamlı fark göstermemektedir. Bakan ve Tombak (2014)araştırmalarında, tükenmişliğin cinsiyete göre anlamlı fark göstermediğini, yaş ve medeni duruma göre duygusal tükenme seviyesinin farkının anlamlı olduğunu bildirmektedir. Benzer bir çalışmada tükenmişliğin boyutlarının medeni durumla anlamlı fark göstermediğini, medeni hale göre ise duygusal tükenmenin anlamlı bir seviyede bekarlarda fazla olduğunu gösterilmiştir (Cemaloğlu ve Şahin. 2007, s.71). Cengil (2010), tükenmişliğin bütün alt başlıklarının yaş, medeni hal ve çocukların sayısına göre anlamlı fark göstermediğini, ancak eğitim durumuna göre duygusal tükenmenin anlamlı derecede fark ettiği bildirmektedir. Çankaya (2017) ise araştırmasında yaşla ilgili bütün tükenmişlik seviyelerinin anlamlı derecede farklılaştığını, duygusal tükenme ve hissizleşmenin genç yaşlarda, bireysel başarının yaşı fazla olanlardan az olduğu göstermektedir. Çalışmada kazanılan sonuçlara göre tükenmişlik seviyesi erkeklerde, 36-45 arası yaşta bulunan katılımcılarda, ön lisans mezunu, bekar, aylık geliri 6001 TL ve daha fazla olan, büyük aileyle yaşayan ve 5-10 sene meslek tecrübesi bulunanlarda fazla seviyededir. Bireysel başarı seviyesi erkek katılımcılarda, 26-35 aralığı yaş olup, ön lisans mezunu, bekar, aylık geliri 6001 TL ve üstünde olan, büyük 
aileyle yaşayan ve beş-on yıl meslek tecrübesi olanlarda daha fazladır. Hissizleşme seviyesi erkeklerde, 26-35 aralığ 1 yaş, ön lisans mezunu, evli, aylık geliri 4001-5000 TL aralı̆̆ı olanlarda, çekirdek aile ile yaşayan ve 5-10 yıl meslek tecrübesi olanlarda daha fazla seviyededir. Toplam tükenmişlik seviyesi erkek katılımcılarda, 36-45 arası yaş olan katılımcılarda, ön lisans mezunu, bekar, aylık geliri 6001 TL ve fazla olanlarda, büyük ailede ve 5-10 yıl mesleki deneyimi olanlarda daha fazladır. Araştırmamızda spor yöneticilerinin tükenmişlik düzeyinin demografik özelliklere göre anlamlı bir fark göstermediği tespit edilmektedir ( $p>0.05)$. Bütün olarak sonuçlara bakıldığında, demografik özelliklerin duygusal tükenme üzerinde gerekli bir etkisinin olmadığı öne çıkmaktadır. Diğer taraftan literatürde çalışılan araştırmalarda, demografik özelliklere göre duygusal tükenmenin farklılık gösterdiği ve göstermediği araştırmalarda mevcuttur (Işıkhan, 2016,s.382-383 ; Marakoğlu vd. 2013,s.107.; Özsoylu, Akyıldız ve Dursun, 2017,s.107-108.; Turgut vd. 2016, s.259-260 ; Yıldırım ve İçerli 2010, s.127-128; Yıldız ve Çolak 2018, s.622-624). Araştırma örnekleminin yöneticiler üstünde dikkat çekmiş olması ve yöneticilerin bütün olarak demografik özelliklerinin birbilerine temas halinde olmasının bu sonuçlar üstünde etkisi olduğunu söylemek doğrudur. Daha fazla örneklem sayısı ve daha değişik demografik yapıdaki gönüllülerden oluşturulan çalışmalarda, bu değişikliğin çok daha anlamlı duruma getirilmesi incelenebilir. Javed vd. (2014) çalışmalarında, iş tatminin, tükenmişliğin belirtisi olan iş sadakatini ve işten ayrılma maksadı ile olumlu seviyede birlikte olduğu bildirmektedir. Orhan ve Komşu (2016) araştırmalarında, iş tatmini ve tükenmişlik arasında olumsuz düzeyde birliktelik olduğunu gözlemlemiştir. Parvin ve Kabir (2011), araştırmalarında iş tatmini, iş şartları, maaş ve promosyon, adalet, iş güvenliği, işletme ve çalışanlarla birlikte anlamlı durumda etkilediğini göstermiştir. Araştırmada yapılan korelasyon analizinde, her ölçeğin boyutlarının kendi içinde anlamlı ilişkisi olması verilerle denkliğini öne çıarırken, tükenmişlik ile iş tatmini arasında birliktelik anlamlı olmaması ise demografik olarak birbirini andıran yönetici benzerliğini ifade etmiştir. Ülkemizde genel olarak yöneticilerin bir kurum ya da bakanlıkta bulunan, ilgili bakanlık ya da kurumun asli görevleri ile doğru bir şekilde, birbiriyle ilişkilidir. Bu durumun çalışmamızın sonuçlarına da etki ettiğini söyleyebiliriz. 


\title{
EXTENDED ABSTRACT
}

\section{The Relationship between Burnout Level and Job Satisfaction Level of Sport Facilities Managers}

\author{
Beyza Özer - Engin Işık Abanoz - Utku Gönener - Ahmet Gönener \\ İstanbul Gelişim University, Kocaeli University
}

The concept of management is present in corporate structures such as public institutions, private companies, local administrations, educational institutions and organizations, as well as in structures at all levels such as a sports club or sports facility. Whenever people come together in teams to achieve common goals, it is essential that each individual's efforts are coordinated to achieve an effective result. Therefore, management involves the successful direction and coordination of human, material, financial and temporary resources within the group, thus making it easier to achieve the goals set by the organization and its members within a specific plan and program framework. Individuals in charge of such managerial work in the organization actually carry out managerial duties. Individuals in management positions such as general manager, deputy general manager, branch managers and deputies, facility managers and assistants in all kinds of institutions and facilities in the sports sector are defined as sports managers. One of the main duties of sports managers is to ensure that the satisfaction of both sports facility users, facility members and sports trainers remains as high as possible. Sports managers experience psychological, physical and mental burnout due to frequent encounters with people due to their profession, while their job satisfaction also decreases. While this decline is reflected in the sports managers, colleagues, environment, family and relationships, it cannot provide the functionality of the institution they are responsible for. The decrease in the performance of sports managers affects the expectations of the institution and the society. Therefore, job satisfaction levels of sports managers are important. On the other hand, understanding the management practices of organizations to solve the problems in management models, organization types, trends, and job satisfaction of employees can help to gain competitive advantage. 
However, this understanding does not guarantee efficiency and effectiveness for the organization, so managing the acquired knowledge will also include adapting to achieve the goals set by the organization. The concept of burnout is defined as a situation related to the physical consumption and development of a negative attitude towards employees and life at work, resulting from long-term work in environments with intense emotional demands. Work life not only provides the staff with the experience of the profession, but also accumulates the different emotions that arise every work day. As a result of these experiences, a person has a mental and emotional attitude to work. The concept of job satisfaction is a term that arises when it matches the characteristics of the job and the requests of the employees and determines the satisfaction of the employee. The concept of job satisfaction is the result of individuals handling things as a positive and enjoyable feeling. Job satisfaction is a function of "values defined as what an individual consciously or unconsciously wants to achieve". The higher the level of these values obtained in business life, the higher the job satisfaction. Job satisfaction or job satisfaction in sports sciences is an important concept for almost all segments of society, from plant workers to facility managers. Also, professional burnout is important for those working in such institutions, and the high quality of the service provided in these institutions may also affect the success of society in general towards sports. Therefore in this study, it was aimed to investigate the relationship between burnout levels and job satisfaction of sports facilities managers. The universe of the research is composed of sports facility managers who are active in 2019 in the Istanbul region and actively functioning in 2019, and the sample is composed of 126 sports facility managers who participated in the research in a random and voluntary manner. A questionnaire including demographic information form, Minnesota Job Satisfaction Scale and Maslach Burnout Inventory was applied to the participants. Among the burnout subscales, the level of emotional exhaustion is low, the personal accomplishment subscale score is high, and the depersonalization subscale is medium. It was determined that the job satisfaction of the participants was high according to the job satisfaction total scores. There is a strong positive correlation between burnout and burnout sub-dimensions $(\mathrm{p}<0.05, \beta=0.664, \beta=0.878, \beta=$ $0.444)$. There is a strong positive relationship between job satisfaction and 
job satisfaction sub-dimensions ( $\mathrm{p}<0.05, \beta=0.917, \beta=0.909$ ). There was no statistically significant relationship between job satisfaction subscales and burnout subscales ( $p>0.05)$. The relationship between total burnout score and job satisfaction total scores was not statistically significant ( $p>$ 0.05 ). As a result, there was no statistically significant relationship between burnout and job satisfaction.

\section{Kaynakça / References}

Akkoç, İ. ve Tunç, H. (2015). Örgüt çalışanlarının tükenmişlik düzeylerinin araştırılması: Balıkesir İl Milli Eğitim Müdürlüğü örneği. Balkesir Üniversitesi Sosyal Bilimler Enstitüsü Dergisi, 18(34), 1-21. doi:10.31795/baunsobed.645363

Altay, B., Gönener, D. ve Demirkiran, C. (2010). Bir üniversite hastanesinde çalışan hemşirelerin tükenmişlik düzeyleri ve aile desteğinin etkisi. Fırat Tıp Dergisi, 15(1), 10-16.

Ardiç, K. ve Polatci, S. (2008). Tükenmişlik sendromu akademisyenler üzerinde bir uygulama:GOÜ Örneği. Gazi Üniversitesi İktisadi ve İdari Bilimler Fakültesi Dergisi, 10(2), 69-96.

Bakan, H. ve Tombak, N. (2014). İdari personelin tükenmişlik düzeylerinin sosyodemografik değişkenler açısından incelenmesi: Muğla Sıtkı Koçman Üniversitesi örneği. The Journal of International Social Research, 7(35), 681695.

Baycan, A. (1985). An analysis of several aspects of job satisfaction between different occupational groups. Yayınlanmamış Yüksek Lisans Tezi, Boğaziçi Üniversitesi, Sosyal Bilimler Enstitüsü, İstanbul.

Cemaloğlu, N ve Erdemoğlu Şahin, D . (2007). Öğretmenlerin mesleki tükenmişlik düzeylerinin farklı değişkenlere göre incelenmesi. Kastamonu Ĕ̆itim Dergisi, 15 (2), 463-484

Cengil, M. (2010). Din görevlileri ve Kur'an kursu öğreticilerinin tükenmişlik Düzeleri. Din Bilimleri Akademik Araştırma Dergisi, 10(1), 79-101.

Çankaya, M. (2017). Özel hastane çalışanlarının tükenmişlik düzeyleri ve bir alan uygulaması. International Journal of Academic Value Studies (Javstudies), 3(9), 1-15.

Eğinli, A. T. (2009). Çalışanlarda iş doyumu: kamu ve özel sektör çalışanlarının iş doyumuna yönelik bir araştırma. Atatürk Üniversitesi İktisadi ve İdari Bilimler Dergisi, 23(3), 35-52. 
Grimaldi Puyana, M., Pérez Villalba, M., Bernal García, A. ve Sánchez Oliver, A. J. (2018). Comparative study of job satisfaction in workers with a degree in Physical Activity and Sports Science, 18(Supplement issue 3)1380-1385

Işıkhan, V. (2016). Çalışanlarda tükenmişlik sendromu. 06 Şubat 2020 tarihinde http://www.solunum.org.tr/TusadData/Book/472/176201612828-32_Bolum 31 Tukenmislik.pdf adresinden erişildi

İnce, N. B. ve Şahin, A. E. (2015). Maslach tükenmişlik envanteri-eğitimci formu'nu türkçe'ye uyarlama çalışması. Eğitimde ve Psikolojide Ölçme ve Değerlendirme Dergisi, 6(2),385-399

Javed, M., Balouch, R. ve Hassan, F. (2014). Determinants of job satisfaction and its impact on employee performance and turnover intentions. International Journal of Learning \& Development, 4(2), 120-140.

Karaçam, A. ve Pulur, A. (2019). Hakemlerin problem çözme becerileri ile öz yeterlikleri arasındaki ilişkinin incelenmesi. Gaziantep Üniversitesi Spor Bilimleri Dergisi, 4(1), 115-130.

Köroğlu, Ö. (2012). İ̧̧sel ve dışsal iş doyum düzeyleri ile genel iş doyum düzeyi arasındaki ilişkinin belirlenmesi: turist rehberleri üzerinde bir araştırma. Doğuş Üniversitesi Dergisi, 13(2), 275-289.

Marakoğlu, K., Kargın, N. Ç. ve Armutlukuyu, M. (2013). Tip fakültesi araştırma görevlilerinde tükenmişlik sendromu ve ilişkili faktörlerin değerlendirilmesi. Genel Trp Dergisi, 1(1), 103-108.

Maslach, C. ve Leither, M. P. (2008). Early predictors of job burnout and engagement. Journal of Applied Psychology, 93(3), 498 -512.

Orhan, U. ve Komşu, U. C. (2016). Akademisyenlerde özyeterlik algılarının ve tükenmişlik düzeylerinin, öğrenmeye yönelik tutuma ve iş tatminine etkisi. Anadolu Üniversitesi Sosyal Bilimler Dergisi, 16(3), 1-18.

Özaydın, M. M. ve Özdemir, Ö. (2014). Çalışanların bireysel özelliklerinin iş tatmini üzerindeki etkileri : Bir kamu bankası örneği. İsletme Araştırmaları Dergisi, 6(1), 251-281.

Özsoylu, S., Akyıldız, B. ve Dursun, A. (2017). Burnout levels and affecting factors in nurses working in a university hospital. Turkish Journal of Pediatric Emergency and Intensive Care Medicine. 4(1), 104-109.

Parvin, M. M. ve Kabir, M. M. N. (2011). Factors affecting employee job satisfaction of pharmaceutical sector. Australian Journal of Business and Management Research. 1(9), 113-123. 
Sánchez, G. F. L., Arturo, F. J. B. B. Y., ve Suárez, D. (2018). Job satisfaction of sports instructors of tennis, padel and swimming. Journal of Physical Education E Sport, 18(Supplement issue 3), 1380-1385.

Soysal, A. (2011). İş yaşamında tükenmişlik. Çimento Endüstrisi İşverenleri Sendikast. 10.08.2019 tarihinde https://docplayer.biz.tr/6861881-Is-yasamindatukenmislik.html adresinden erişildi.

Şıklar, E , Tunalı, D . (2012). Çalışanların tükenmişlik düzeylerinin incelenmesi: Eskişehir örneği. Dumluptnar Üniversitesi Sosyal Bilimler Dergisi 33 ,75-84.

Taşğın, Ö. (2004). Gençlik ve spor genel müdürlüğü merkez ve taşra örgütü yöneticilerinin tükenmişlik düzeylerinin iş doyum düzeylerine etkisi. Selçuk Üniversitesi İletişim Fakültesi Akademik Dergisi, 3(3), 170-175.

Turgut, N., Karacalar, S., Polat, C., Kıran, Ö., Gültop, F., Türkmen Kalyon, S., ... Kaya, E. (2016). Uzmanlık eğitimindeki doktorlarda tükenmişlik sendromu. Turkish Journal of Anesthesia \& Reanimation, 44(5),258-264.

Yakut, H. İ., Gül Kapısız, S., Durutuna, S. ve Evran, A. (2013). Sağlık alanında çalışma yaşamında tükenmişlik. The Journal of Gynecology - Obstetrics and Neonatology. 10 (38), 1564-1571.

Yıldırım, M. H. ve İçerli, L. (2010). Tükenmişlik sendromu: maslach ve kopenhag tükenmişlik ölçeklerïnin karşılaştırmalı analizi. Organizasyon ve Yönetim Bilimleri Dergisi. 2(1), 123-131.

Yıldız, S. B. ve Çolak, U. (2018). Liderlik davranış tarzlarının örgütsel tükenmişlik ve işten ayrılma eğilimlerine etkileri: Seyahat acentaları üzerine bir araştırma. Manas Sosyal Araştırmalar Dergisi. 7(4), 607-632.

Yelboğa, A. (2007). Bireysel demografik değişkenlerin iş doyumu ile ilişkisinin finans sektöründe incelenmesi. Çă̆ Üniversitesi Sosyal Bilimler Dergisi. $4(2), 1-18$.

\section{Kaynakça Bilgisi / Citation Information}

Özer, B., Abanoz, E. I., Gönener, U. ve Gönener, A. (2021) Spor tesisi yöneticilerinin tükenmişlik düzeylerinin iş doyum düzeyleri ile ilişkisi. OPUS-Uluslararası Toplum Araştırmaları Dergisi , 17(36), 2957-2974. DOI: $10.26466 /$ opus. 688985 